\title{
Muslim learners' religion expression through attire in culturally diverse public schools in South Africa: A cul-de-sac?
}

\author{
WJ van Vollenhoven and Seugnet Blignaut
}

\begin{abstract}
Opsomming
Internasionale menseregte instrumente stel dit ten doel om almal se menseregte te bevorder. Nieteenstaande het nie alle lande die instrumente onderteken nie en skaar diesulkes hulle onder hul eie outoriteit bv Moslems wat die Shari'ah wet as oppergesag bo die handveste van menseregte ag. Gevolglik is daar spanning wanneer multikulturele skole ' $n$ balans probeer uitoefen tussen menseregte en godsdienstige dogma, bv waneer gedragskodes ' $n$ kleredragbeleid bevat wat nie voorsiening maak vir die godsdienstige uitdrukking van minderheidsgroepe soos bv die Moslem nie.
\end{abstract}

Terwyl die kulturele diversiteit van publieke skole in Suid Afrika 'n gegewe is, fokus die artikel op die spanning tussen die verskillende opinies oor menseregte tussen leerders van verskillende kulturele en godsdienstige agtergronde. Alhoewel die fokus van die artikel hierdie spanning is bepaal hierdie artikel hom slegs as voorbeeld by die Moslem leerder in Suid Afrikaanse openbare skole en die uitdaging aan skoolowerhede met die implimentering van menseregte midde die reg tot vryheid van godsdienstige uitdrukking.

\section{- Dr WJ van Vollenhoven}

Department of Education Management and Policy Studies, University of Pretoria

\section{- Prof AS Blignaut}

Faculty of Humanities

Tshwane University of Technology

\section{INTRODUCTION}

Photographs of Iraqi prisoners' abuse by American soldiers sent shockwaves throughout the world during the Iraq War (Wikipedia, 2003). This again raised the question of human rights and how these rights are balanced in diverse societies. This article intends to focus on the relationship between human rights and religious requirements in the day-to-day functioning of public schools.

\section{BACKGROUND}

South Africa has just celebrated twelve years of democracy. After the first democratic elections in 1994, South Africa (for the first time) developed a Bill of Rights which is entrenched in chapter two of the Constitution of South Africa, Act 108 of 1996 (the Constitution). All persons in South Africa can now lay claim to rights such as freedom of expression ${ }^{1}$, freedom of religion $^{2}$, human dignity ${ }^{3}$ and equality. ${ }^{4,5}$ Although all persons may claim their rights as set out in the Bill of Rights, not everybody's rights are always protected to the same extent in a diverse country with a myriad of cultural and religious groups. When looking at the right to freedom of religious expression of the Muslim in public schools, this tension is noticed.

Human rights instruments have been established internationally to protect people against interference by government. Although most countries endorse the use of instruments that ensure uniformity and protection for everyone, so-called universal rights appear to be less "universally" applied. Muslim countries have been reluctant to endorse international human rights instruments since they feel that Shari'ah Law enforces human rights (Moosa, 1998: 508-524). Some argue that this prevents the establishment of human rights standards in Muslim countries. However, where Muslims constitute a religious minority, they develop an interest in secular constitutionalism and respect for universal human rights (Moosa, 1998: 508-524). Although some Muslim governments have been supportive of the development of United Nations (UN) instruments to protect human rights, the acceptance of these instruments must be compatible with principles of Islamic law (Moosa, 1998: 508-524; Yilmaz, 2001: 297-308).

\footnotetext{
Section 16 of the Constitution.

2 Section 15 of the Constitution.

3 Section 10 of the Constitution.

4 Section 9 of the Constitution.

Section 7 of the Constitution.
} 
This clearly creates a challenge, as Muslims must cope with the dual identity of being both Muslim and a citizen of a westernised country. Muslim personal laws have changed little (Moosa, 1998: 508-524). Khan (2003: 44) adds, that in absence of a codified legal system based on Shari'ah Law, modern Muslim nations misuse the injunctions provided by Shari'ah. The tension comes when Shari'ah law, which has the status of moral law, is applied within an English common legal system.

On the surface the Islamic Declaration on Human Rights (IDHR) compares favourably with international human rights instruments such as the Universal Declaration on Human Rights (UDHR). A closer look, however, highlights a clear difference. The IDHR comes from Shari'ah Law, which does not provide for individual human rights (Moosa, 1998: 508-524). This difference of interpretation on human rights leads to tension in, inter alia, the culturally diverse public school and manifests itself in the religious attire. Despite the fact that Muslim learners can claim their rights according to the Constitution, the religious principles and Muslim rights of the Muslim learner appeal to a higher authority, namely the Shari'ah Law and its values - rather than to the fundamental, constitutional, protected rights in the South African Bill of Rights.

This dichotomy creates conflict not only for the Muslim learner, but also for the educator and other learners in whose class the Muslim learner sits. This article, therefore, hopes to raise awareness of the challenge to balance Muslim rights with rights articulated in the Constitution. Public school authorities and educators should be aware of this tension when disciplining learners in a multicultural school.

\section{THE DEVELOPMENT OF HUMAN RIGHTS}

Before focusing on the development of human rights, it is necessary to define what is meant by this concept. Every person owns human rights merely because of the fact that they are born and thus for being a human being (Kleyn \& Viljoen, 2002: 234). Human rights belong equally to all human beings independent of economic, social, political, cultural and religious context (1948: preamble). Although neither absolute nor unlimited, they are universal, inalienable and enforceable by government. Human rights may be limited if the bearers do not exercise their corresponding duty or when different rights are in conflict (Bray, 2000a: 28; Bray, 2000b: 44; Van Vollenhoven, 2003: 15). One of the earliest principles to address human rights originated among the lawyers of the $11^{\text {th }}$ and $12^{\text {th }}$ centuries and is the legal maxim "lex injusta non est lex" or "an unjust law is not a law" (Sieghart, 1985: 22). The principle implies that unjust laws passed by rulers do not have to be obeyed (Alston, 2002: 27).

Although the United States Federal Constitution and the Declaration of the Rights of Man and the Citizen (Déclaration des droits de l'homme et du citoyen) are the oldest constitutions to protect citizens from unfair rulers or governments, the principle that all people are created equal, is first found in the 1776 American Declaration of Independence. Brinkley (1993: 20; 159) points out that amendments to the Constitution of the United States of America in 1791, the Bill of Rights offered even greater protection to its citizens than before. According to Adams (1997: 501-513) the Constitutions of the USA and France first explicitly guaranteed human rights and these documents owe much to the 18th century thinkers of the Enlightenment.

The Second World War (1939-1945) generated momentum for external constraints on governments (Bobbio, 1996: 47) as they could no longer be left to their own devices (Sieghart, 1985: 33). This first code of international human rights was drafted as the Charter of the United Nations (The Charter), 1945. Dlamini (1995: 15) rightfully argues that the Charter marked a new chapter in the history of human rights. The Charter was amended, and in 1948 the United Nations (UN) passed the United Declaration on Human Rights (UDHR). The adoption of the declaration represented a great achievement and enjoyed immediate authority, political as well as moral (Humphrey, 1979: 28). The European Convention on Human Rights (ECHR) followed in 1950, demonstrating that many countries were, at that stage, aware of the necessity for protecting human rights.

Although the UDHR was the first comprehensive international document on human rights, it was followed by regional and international declarations and conventions which also exerted influence once they had been ratified. The absence of important non-Western cultures in the drafting of human rights instruments has been a serious concern over recent years, as many of them do not share Western countries' views on human rights (An-Na'im \& Deng, 1990: 138). Although governments should guarantee the rights of every citizen, there are some that still, for cultural or political reasons, practice serious violations of human rights (Humphrey, 1979: 32). Human rights have been globalized and today span all borders and governments mechanisms (McCorquodale \& Fairbrother, 1999: 735-736). Internationally, governments can intervene in each other's countries, should the human rights of the citizens be violated.

South Africa joined the international community in protecting human rights when the first democratically elected government accepted the Constitution. The Constitution is one of the most modern and advanced constitutions in the world, especially with its Bill of Rights in chapter two (Malherbe, 2003: 432-464). The new government adopted the Constitution with the Bill of Rights that entrenches the fundamental human rights of everyone in South Africa. ${ }^{6}$ It is thus imperative for South Africans to consider how international law addresses human rights, and more specifically, to become aware of how international courts interpret human rights. ${ }^{7}$

As this article assesses the challenge of achieving a

\footnotetext{
${ }^{6}$ Section 7 of the Constitution.

7 Section 39 of the Constitution.
} 
balance in multicultural schools in South Africa between Islamic rights and those articulated in the Constitution, it will now change to Islam's view of human rights.

\section{THE UNIVERSAL ISLAMIC DECLARATION OF HUMAN RIGHTS}

Some authors insist that Islam developed human rights in the seventh century (Mayer, 1995: 2). Diplomats and scholars argue that Islamic law embodied the basic concepts and principles of human rights from the outset (Donelly, 1982: 303-316). A survey of pre-modern Islamic intellectual history, however, reveals that no settled Islamic doctrine on rights or proto-rights existed then (Mayer, 1995: 9), although Muslim law provides rules similar to human rights' declarations.

Muslims followed the major teachings of the Quran during their first five centuries of Muslim civilization (Khan, 2003: 8). At the height of the Industrial Revolution most Muslim nations found themselves under colonial rule (Khan, 2003: 5), with little regard for their human rights. Muslims saw the rise of European democratic institutions and concepts as a threat, because the authoritarianism of democracy redefined the power and functions of governments, and Muslims believed this inconsistent with their religion per se (Khan, 2003: 17).

Muslim countries achieved independence from colonial rule, but only after the violence to which they had been subjected during colonial rule intensified their conviction that the Western model of the relationship between religion and politics was inherently unjust (Hollenbach, 1982: 94-109). Most Muslims who ruled after decolonisation were not au fait with developing a legal system incorporating human rights. The absence of such a legal system ignored the interests of common people in the name of national and religious causes (Khan, 2003: 90).

Muslims share no common understanding of Islamic law. (An-Na'im \& Deng, 1990: 138; Yilmaz, 2001: 297308). The Universal Declaration of Islamic Human Rights (UDIHR) may be the equivalent of the United Nations Charter (UNC). It addresses discrimination and offers an authoritative view on human rights, which places it in a religious rather than a social context (Moosa, 2000: 511; Moosa, 1998: 508-524).

Its Preamble states the purpose of the UDIHR is to establish an Islamic order in which humans are equal (Moosa, 2000: 511). In addition, the Arabic version states, "by the terms of our primeval covenant with God, our duties and obligations has priority over our rights", thereby reaffirm the traditional idea that Islam provides a scheme of duties rather than rights. It stipulates that nothing is equal in the world and that man was "created to fulfil the Will of God on earth" (1981: preamble). The individual was born to fulfil the "Will of God on earth" rather than to enjoy personal, protected human rights and freedoms. It is clear that the UDIHR will deny rights, including those guaranteed by international human rights law (Mayer, 1995: 51). This is demonstrated in the Preamble that holds that the duties and obligations of the Muslims have priority over their rights.

Islam emphasises the relationship between governments and Islamic citizens; and although its basic values differ little from the human right's code of international covenants, the Law of Allah takes priority over human rights. One could argue that the UDIHR is looking at "collective human rights" in contrast with the Western idea of individual human rights.

\section{DIFFERENCE OF INTERPRETATION OF THE UNIVERSAL DECLARATION ON HUMAN RIGHTS AND THE UNIVERSAL ISLAMIC DECLARATION OF HUMAN RIGHTS}

Human rights intend to protect individuals from infringement by the state and to limit the state's powers. Moosa (2000: 511) adds that human rights in the Western world require the state to enforce those rights. Islam recognises no separation between the state and the individual. Muslims believe human rights belong to God; therefore, "human" rights do not exist. There are duties owed to God and man.

Singh (1998: 41) adds to this issue: "There is a fundamental difference in the perspectives from which Islam and the West each view the matter of human rights". The Western perspective may be called anthropocentric in the sense that man is regarded as constituting the measure of everything. He is the starting point of all thinking and action. The perspective of Islam on the other hand is Theo centric, which is God conscious. But many scholars of Islam believe that Islam do support human rights because so many Muslim countries' constitutions are built on the Western constitutional model and many Muslim countries have become signatories to human rights conventions. They have also, in some cases, contributed to the formulation of human rights instruments (Moosa, 1998: 508-524).

Although many countries ratified UDHR, its content remains controversial in the Muslim world (Moosa, 1998: 508-524). Religious provisos take precedence over the declarations of Western society. In the Muslim world personal law is always exempt from constitutional scrutiny. A survey done in 1989 in England indicates that $66 \%$ of Muslims would follow Muslim law rather than English law in case of conflict (Yilmaz, 2001: 297-308). It seems on the surface as if Muslims do not believe in human rights, as they believe that all rights belong to God (Moosa, 1998: 508-524). One might argue that cultural or religious obstacles prevent the establishment of human rights' standards in Muslim countries. Muslims in countries where they constitute a religious minority, tend to develop an interest in secular constitutionalism and respect for universal human rights. Although some Muslim governments have been supportive of and have developed UN instruments to protect human rights, the acceptance of these instruments is always subject to the condition 
that their obligations be compatible with principles of Islamic law (Moosa, 1998: 508-524). This clearly creates a challenge, as Muslims are required to cope with the dual identity of being both Muslims and citizens of a westernised country.

An examination of individual human rights reveals noteworthy discrepancies between the rights offered in the UDHR and the rights offered by the Universal Declaration of Islamic Human Rights and in the constitutions of Islamic countries. The Islamic declaration in the Arabic version states, "all rights are guaranteed only to the extent that they are protected by Islamic law" (An-Na'im \& Deng, 1990: 138).

An-Na'im (1987: 1-18) states that although most of the constitutions of modern Muslim (also the UDIHR) provide guarantees against religious discrimination, Shari'ah Law provides the foundation of most constitutions (also the UDIHR) . Traer (1991: 111) avers that the culture of Islam denies freedom of religion and conscience because, under Shari'ah Law, a Muslim who abandons Islam can be sentenced to death. The UN's goal of equality between sexes can never blossom in Muslim countries as it is inconsistent with traditional Islam (Moosa, 2000: 511).

Although the UDIHR guarantees gender equity, the Egyptian constitution, for example, provides equal rights "as far as it does not conflict with Islamic law" (Moosa, 2000: 511). This pattern remains consistent in most Muslim countries. Although women and men have equal rights according to the UDIHR, the male still plays the dominant role and assumes the head of the family (Jomier, 1989: 75). Although the UDHR guarantees gender equity, according to Shari'ah Law women may assume only certain roles. Appropriate roles for women include marriage and motherhood, and when women participate in higher education and paid work, they must be consistent with feminine vocations like teaching and studying medicine to treat women and children (Jomier, 1989: 75).

Islamic law is similar to ancestral law. Neither distinguishes between legal, moral and religious rule. Both cultivate gender inequality (Alston, 2002: 78; Benedek, 1990: 247-256; Mboya, 1992: 34-45; The Convention on the Rights of the Child, 1990: article 2). Both laws believe themselves superior to constitutional law. This creates tension in some Western societies, e.g. religious expression through attire.

Although the UDIHR provides for freedom of expression, the Quran requires, for example, that as soon as a girl reaches puberty, only her eyes should be visible (Jomier, 1989: 75). Therefore, Shari'ah Law limits a woman's constitutional right to freedom of expression.

The UDHR recognises the equality of all human beings. The UDIHR also provides for equality, but minorities in Muslim states do not share the same rights as Muslims. An-Na'im (1987: 1-18) points out that Shari'ah Law divides the Islamic state into three categories: Muslim people of the book (dhimmih's), nonMuslims who believe in one of the heavenly revealed scriptures like Jews and Christians, and last, the unbelievers. Only Muslim males enjoy full citizenship in the Islamic state, and dhimmihs may neither participate in state affairs and nor publicly preach their faith.

Moosa (2000: 511) gives a few reasons for the differences between Islamic and Western Human Rights:

1. Muslim countries do not interpret human rights documents in the same way as Western countries, especially when it comes to religion.

2. The language in the UDHR differs from the language used in scriptures like the Quran.

3. Adherence to international law and the actual implementation of international law creates a discrepancy. Human rights tend to be static in most Muslim countries.

4. Western cultures are individualistic, Islam sees the individual as part of a group.

An-Na'im (1987: 1-18) mentions that Islamic sources were interpreted when Shari'ah Law was developed. Shari'ah Law is thus no more than the early Muslims' understanding of the sources of Islam, people invariably influenced by their experiences and perception of the world. Therefore, rights contained in an Islamic system are not equal to rights in international law. It follows that in Muslim law, a right is allowed only under Shari'ah Law. Where the Shari'ah Law reigns supreme to international or national legislation, tension develops between governments and their Islamic citizens.

\section{SOUTH AFRICA}

Human rights in South Africa reflect the values of the Constitution: ${ }^{8}$

a. Human dignity, the achievement of equality and the advancement of human rights and freedoms.

b. Non-racialism and non-sexism.

c. Supremacy of the constitution and the rule of law.

d. Universal adult suffrage, a national common voters roll, regular elections and a multi-party system of democratic government, to ensure accountability, responsiveness and openness (Constitution of the Republic of South Africa, 1996).

These values should also be aligned with the democratic values of human dignity, equality and freedom. ${ }^{9}$ Any decision courts make limiting rights with the limitation clause ${ }^{10}$ should be guided by these values. Balancing fundamental rights such as the right to freedom of religion and the right to freedom of expression with the right to equality is not an easy task. On one hand, every person in South Africa has the right to freedom of religion and expression, yet they are all members of society in a democracy underpinned by the values in section 1 of the Constitution. Surely if these rights contradict the purpose of nation building or democracy, they can be limited. However, this might endan-

\footnotetext{
8 Section 1 of the Constitution

9 Section 7 of the Constitution

${ }^{10}$ Section 36 of the Constitution

${ }^{11}$ Section 9 of the Constitution
} 
ger the right to equality. Thus, although the right to equality $^{11}$ as well as the right to freedom of association apply to minority groups in South Africa; such groups (including Muslims) are subject to the same rules as everyone else in the country. In this regard, the right to freedom of association ${ }^{12}$ of individual persons encompasses the right to associate with a specific cultural or religious group, which refers to the right to develop independent schools. Different rights need to be balanced when in conflict with other fundamental rights of other persons in the country in building our democracy. The challenge concerning rights like these guaranteed in the Constitution, is thus the process of incorporating personal law, such as Shari'ah Law, into civil law, such as human rights in the Bill of rights, which, according to Yilmaz (2001: 297-308), works against the notion of an uniform legal system. On the other side, one must never forget the values that underpin the Constitution when these rights of minority groups are limited.

\section{PROBLEMS IN SCHOOLS}

School principals in South Africa need clear instruction on how to respect and honour the constitutionally entrenched right to all (Educators need to be Educated, 1998: 6). Multicultural public schools must balance constitutionally protected rights, e.g. the right to equality, ${ }^{13}$ human dignity, ${ }^{14}$ freedom of religion, belief and opinion, ${ }^{15}$ freedom of expression, ${ }^{16}$ and freedom of association. ${ }^{17}$ South Africa, as a member of the UN, has a Muslim population of nearly half a million. The dichotomy between Muslim and Western Human Rights poses a threat to educators and school managers in balancing human rights in South African public schools. Educators are faced with an enormous task of incorporating learners into multicultural classrooms under the guidelines of the Constitution.

Muslims acknowledge human rights featured in Western constitutions. Muslims do generally support the UDHR and lead the third world in stressing the newer social, economic and individual rights. Muslims stress basic rights as long as they square with tradition (Traer, 1991: 120). Educators face the dilemma. Although South Africa supports human rights with its entrenched Bill of Rights in chapter two of the Constitution, some Muslim learners view their religion and Shari'ah Law superior to the human rights in the Constitution. This creates not only a point of external conflict in schools but also a point of internal conflict for the Muslim learner having to choose between religion in terms of Shari'ah Law and the adherence to human rights in the Constitution between secular and religious law.

In terms of section 8 of the South African Schools Act, Act 84 of 1996 (SASA), the School Governing Body

\footnotetext{
12 Section18 of the Constitution

13 Section 9 of the Constitution

14 Section 10 of the Constitution

15 Section 15 of the Constitution

16 Section 16 of the Constitution

17 Section 18 of the Constitution
}

must adopt a Code of Conduct for learners after consulting with parents, educators and learners. If this Code of Conduct is adopted it becomes law. South Africa with its colonial and Calvinistic influence has a tradition of wearing school uniform. Once the Code of conduct for learners is adopted, learners would break the law if they do not wear the correct school uniform and can therefore be punished (South African Schools Act, Act 84, 1996: 8(4)). Some interpret the improper wearing of traditional school wear as an act of rebellion (Dudley, 2004: 14). Yet all persons in South Africa have the right to freedom of religion and the right to freedom of expression. Should a Muslim girl wearing a headscarf to school be punished or must this be allowed on grounds of human rights?

At Sir John Adamson High School in Johannesburg, Lamiah Khan, a 13-year-old Muslim girl was ordered to remove her headscarf because she was violating the dress code of the school (Rondganger \& Govender, 2004: 3). This requires balancing rights. The School Governing Body can democratically determine school rules and dress codes ${ }^{18}$ while learners have the right to freedom of religion and expression. On the one hand the School Governing Body violated Lamiah's right to freedom of religion; on the other hand she acted illegally by breaking a democratically adopted dress code which is a form of subordinate (administrative) legislation.

In another incident, a Muslim girl was excluded from school for wearing her traditional scarf with her uniform (Striving for Equality, 1998: 20). The balance/ tension here again is between the wearing of legally correct school uniform versus the right to religion and what might even come down to discrimination. The fact that schools actually exclude learners from school or suspend them for breaking the dress code, indicates the tension between the prior Christian National Education and the respecting of fundamental rights (Vanderhaeghen, 1998: 6). The exclusion does not only violate the girl's right to education, but also her right to freedom of expression, freedom of religion, right to dignity and equality. School authorities balance with difficulty between Western values and the values that underpin the new South Africa (Ismael, 1998: 6; Van Vollenhoven, 2005: 202).

Attending prayers at Mosques on Fridays during school hours presents another conflict. Again, in terms of Section 20(1)(f) of SASA School Governing Bodies of public schools must determine the times of the school day. In terms of section 7 of SASA, religious observances may be conducted at a public school under rules issued by the School Governing Body. The question remains whether School Governing Bodies must give learners time off to attend these observances during school hours at mosques off the school premises. This debate intensifies considering the school's duties as in loco parentis. ${ }^{19}$ For example, could the parents sue the school should their children be involved in an accident while on their way to a reli-

\footnotetext{
18 Section 8 of SASA.

19 In the place of the parent.
} 
gious observance at a Mosque during school hours? Can parents and religion groups expect schools to give their children off to attend these observances? Do they have a right to claim this time off because of their right to freedom of religion? Should the schools abrogate their responsibilities to facilitate learning?

The right to religious expression in schools can become a thorny issue. In terms of section 20(1)(c) of SASA the School Governing Body must develop a mission statement that reflects the value system underpinning their religion. Can parents from a specific religious denomination have a claim against the School Governing Body, stating that the values of a specific religion as stated in the legal mission is promoted at the expense of other religions? One should remember that in multi-faith public schools, all religions should receive equal treatment in terms of section 7 of SASA.

According to Van Vollenhoven and Glenn (2004: 148152) Layla Cassim was suspended from school for pinning her viewpoint (the Palestinian one) on the school's notice board. She did this in response to an article expressing an Israeli viewpoint. Bearing in mind Crawford College's tension between Islamic and Jewish learners (Ismael, 1999: 1-2), school authority might prohibit such political expressions fearing disruption in the school. Schools however must be cautious not to violate human rights in the process and must always when limiting rights keep the cultivation of a human rights culture in mind. Perhaps an answer lies in either encouraging all political views or allowing none.

In another incident, Yusuf Bata refused to shave his beard despite the school's prohibition against facial hair. When a man does not shave it indicates he knows the Quaran by heart. The principal of this school, Mr Viljoen, stated that the multicultural school posed a challenge (Pretorius, 1998: 8) and that school rules could not be bent to accommodate one culture among thirteen different cultures (Eshak, 1998: 8). Are Muslim children at a disadvantage when educators stereotype them as medieval? (Noorani, 2002: 93). Many Muslim girls cannot reach their full potential because they may, according to Shari'ah Law join only certain occupations.

Van Vollenhoven (2005: 164-165) concluded in his empirical study that learners seem to absolutise the right to freedom of religious expression:

You can wear what you want and do with your hair as you want. ${ }^{20}$

I don't think that should be. I think the school should respect your cultures and images and things like that. So they should find space within the code of conduct for things like your religion and culture.

\footnotetext{
20 Jy mag aantrek soos jy wil en met
} jou hare doen wat jy wil.
Again, the dreadlocks are fine, because I don't think it [sic] would bother anyone. The first week it [sic] might bother them then they will be accustomed to it [sic]. ${ }^{21}$

She is going her own way and she does not bother the rest of us or our religion. She doesn't comment against our beliefs. I think this is the same as the previous earring scenario. Then you have the right to do it. I think the hat is taking it a bit too far ...22

If it's got [sic] some symbolic meaning to it. It is all right. But to wear a stud or sleeper for a guy it does not really represent anything. It is just there you know...

But this thing is that people believe in your religion that you have to show other people that you are religion [sic]. With the freedom of expression you are showing kind if it's true that you can wear an earring it's true what you are trying to say that an earring and that is the same thing, but there is a difference. Because one is expressing your religion and believe and the other one is also a believe [sic] but it's not the proper place to express it. In your religion you express throughout your whole life and just to wearing [sic] an earring is a fashion statement kind of thing. It's like a phase or fashion statement. And that kind of statement isn't the school and the place for that. Religion is throughout your whole life and these kinds of statements are not at school. Like other religions Christians wear crosses to show that they are religious. Jewish people wear their hats on top [sic] and it's go on like that [sic]. Those places should be everywhere in your life and this is just fashion or expression there is place for that like when you go out to shops and things like that or paint your hair red or whatever you want to do.

Some learners in his study argue that religious expression is subsumed by the right to freedom of expression: "That you have the right to express who you are and your religion/culture" (Van Vollenhoven, 2005: 165). There is a tendency among learners to absolutise this right by indicating that, under the right to freedom of expression, they are allowed to pray anywhere and at any time: "Dress as I like, pray where ever and when ever..." (Van Vollenhoven, 2005: 146). The right to express your religion is also associated with the right to express your religion through traditional attire: "You can state your viewpoint on certain things. Maybe even fashionably, e.g. if you [sic] a Muslim woman you'll express parts of your religion through your traditional attire" (Van Vol-

${ }^{21}$ Weer, die dreadlocks is fine, want ek dink nie dit gaan enigiemand so baie pla nie. Die eerste week gaan dit die mense pla, dan is hulle gewoond daaraan.

22 Sy gaan haar eie gang en sy los die res van ons en ons geloof. Sy gaan nie teen in wat ons glo nie. Ek dink dan net dit is dieselfde as die oorbelstorie van die vorige een. Dan het jy die reg om dit te doen. Ek dink die hoed is bietjie ver, want ... 
lenhoven, 2005: 147). That this tendency is vibrant in the community is clear from, among others, the Antonie court case (Antonie, 2002). In this regard the plaintiff in the Antonie case responded during an indepth interview about the absolutising of the right to freedom of religious expression: "...there is only a certain extent that they can use it [the right to freedom of expression] and that is their religious freedom and the school cannot deny them that" (Van Vollenhoven, 2005: 190)

On the other hand, Judge Sachs states in Christian Education South Africa v Minister of Education that "... believers cannot claim an automatic right to be exempted by their beliefs from the laws of the land" (Christian Education South Africa v. Minister of Education, 2000: 779). This principle suggests that learners cannot claim the right to wear religious attire to school because of their right to freedom of religion and/or the right to freedom of expression. Sachs further states that "...the State should, wherever reasonably possible, seek to avoid putting believers to extremely painful and intensely burdensome choices of either being true to their faith or else respectful of the law" (Christian Education South Africa v. Minister of Education, 2000: 779). This judgement suggests that personal human rights, e.g. to freedom of religion or freedom of expression, can be limited, provided the limitation is executed in a reasonable manner. To make balancing this maze of rights even more difficult, it should be done in accord with our democratic value system. ${ }^{23}$ In other words, although the right to freedom of religious expression can be limited, it would be $a b$ surd to expel or even suspend a learner for breaking a school rule by wearing religious attire or a Rastafarian hairstyle to school as this would not be in line with the value of tolerance as indicated in The Manifesto on Education and Values (DoE, 2001). The question should be whether religious attire and hairstyles will negatively influence education.

Balancing freedom of religious expression and the school Code of Conduct will not be easy. Should the democratically adopted Code of Conduct that should be in line with the Constitution and which is subordinate law prevail or is the right to freedom of religious expression in terms of the Shari'ah Law supreme? Surely, some learners believe absolutely in their right to freedom of religious expression (Van Vollenhoven, 2005: 164-165). Yet authorities also have the charge to create order and harmony at school. Balancing these conflicting interests is a delicate job. Learners need to realize that every human right does have a corresponding duty and can thus be limited if the responsibility that the right poses on its bearer does not prevail. Furthermore, when different human rights are in conflict, they can be limited when it is reasonable and justifiable in an open democracy based on human dignity, equality and freedom. Neither school authorities nor learners are clear how this process should be dealt with in practice. Hence, more critical incidents at schools.

\section{CONCLUSIONS AND RECOMMENDATIONS}

Muslims are no longer "out there". They are part of work, neighbourhoods and public schools in South Africa. They are part of our nation and identifiable through their religious expression through attire such as headscarves. Traditional Muslims view the Shari'ah Law superior to the Constitution. The $21^{\text {st }}$ century emphasises human rights more than earlier times. There is a need to revitalise and redefine human rights within every context of society, especially in schools.

There is no easy solution to the problems between international human rights and Islamic law. Few think a solution likely soon, because a solution may mean rejecting Islamic law or total reconstruction (Moosa, 2000: 511). School authorities need to consider these conflicting rights when administering school discipline. The multicultural public school poses a challenge to balance Islamic rights with those of the Constitution. School authorities should realise the fundamental difference in interpretation of human rights between the Muslim and the Western learner. If school authorities are not sensitive to this phenomenon, they may be sued for infringing on the rights of some learners. Education policy needs to teach learners about their rights. School authorities should assist educators in balancing learners' rights in schools in a Western society.

Human rights at public school should be implemented and balanced according to the value system that underpins South Africa, as spelled out in the Preamble to the Constitution. This is consistent with the Guidelines for Consideration of School Governing Bodies in adopting a Code of Conduct for learners. This says that schools should focus on a positive discipline and the need to achieve a culture of reconciliation, teaching, learning and mutual respect and the establishment of a culture of tolerance and peace in all schools (DoE, 1998 sections 1.4, $1.5 \& 2.3$ ). Therefore, the question at stake is: what is the educational sense of preventing a girl from wearing a scarf or dreadlocks to school? If the wearing of such attire does not interfere with the purpose of education, it certainly creates discrimination (Rademeyer, 2006: 6; Van Vollenhoven, 2005: 209). By this means Shari'ah Law or rights of minority groups does not get supremacy to the Constitution but Constitutional entrenched human rights are balanced according to the values underpinning the democracy.

In order to unite in our diversity, all stakeholders in schools need to respect and tolerate each other's differences. It is important to create equality in our schools by respecting every individual's right to human dignity in a culture that promotes and advances human rights and freedom with the purpose of enhancing a united democracy. Muslim learners in culturally diverse public schools in South Africa should not find themselves in a cul-de-sac.

\footnotetext{
${ }^{23}$ Sections 1 and 7 of the Constitution.
}

\section{REFERENCES}


ADAMS, M. 1997. Individualism, moral autonomy and the language of Human Rights. South African Journal on Human Rights, 13(4):501-513.

ALSTON, KS. 2002. The Constitutional Right to Freedom of Expression: An Exploration of its Relevance to the South African School Community. Unpublished PhD, University of the Free State. Bloemfontein. AN-NA'IM, AA. 1987. Religious minorities under Islamic Law and the limits of cultural relativism. Human Rights Quarterly 9:1-18.

AN-NA'IM, AA, \& DENG, FM. 1990. Human rights in Africa-cross-cultural perspectives. Washington DC. The Bookings Institutions.

Antonie v. Governing Body, Settlers High School and Others, 4: 738. SA. 2002

BENEDEK, W. 1990. The judiciary and Human Rights in Africa. Human Rights Law Journal, 11(1-2):247256.

BOBBIO, N. 1996. The age of rights. Cambridge. Polity Press.

BRAY, W. 2000a. Foundations of Law and Education Law. Pretoria. CELP.

BRAY, W. 2000b. Human Rights in Education. Pretoria. CELP

BRINKLEY, A. 1993. The unfinished nation: a concise history of the American people. New York. McGraw Hill.

Christian Education South Africa v. Minister of Education, 4: 757. CC. 2000.

Constitution of the Republic of South Africa,

RSA.1996.

DLAMINI, CRM. 1995. Human rights in Africa: which way South Africa? Durban. Butterworths.

DOE. 2001. Manifesto on Values, Education and Democracy. Available online from http://www.education.gov.za/. Accessed on 14 February 2007. DONELLY, J. 1982. Human rights and human dignity: an analytic critique of on-western conceptions of human rights. The American Political Science Review, 76:303-316.

DUDLEY, C. 2004, 4 February. Respect headscarves. The Sowetan:14.

EDUCATORS NEED TO BE EDUCATED. 1998, October. The Leader:6.

ESHAK, B. 1998. Devout boy banished for wearing a beard. Sunday Times:8.

HOLLENBACH, D. 1982. Human rights and religious faith in the Middle East: reflections of a Christian theologian. Human Rights Quarterly, 4:94-109. HUMPHREY, JP. 1979. Human rights: thirty years after the Universal Declaration. In RAMCHARAN, BG (Ed.). London. Nijhoff.

ISMAEL, F. 1998, 29 November. Muslim pupil suspended over essay. Sunday Tribune:6.

ISMAEL, F. 1999, 19 September. HRC finds that schoolgirl's right to freedom of expression was violated. The Sunday Independent: 1.

JOMIER, J. 1989. How to understand Islam. London.
SCM Press Ltd.

KHAN, MA. 2003. Human rights in the Muslim world fundamentalism, constitutionalism and international politics. USA. Carolina Academic Press.

KLEYN, D, \& VILJOEN, F. 2002. Beginner's Guide for Law Students (3rd ed.). Cape Town. Juta.

MALHERBE, EFJ. 2003. Advancing social change: recent human rights developments in South Africa. Tydskrif vir die Suid-Afrikaanse Reg, 2003(2):432464.

MAYER, AE. 1995. Islam and human rights. Boulder. Westview.

MBOYA, ER. 1992. The Compatibility of Regional Human Rights System with International Standards. In ERDE, A \& HAGTVET, B (Eds.), Human Rights in Perspective (pp. 34-45). Cambridge. Blackwell. MCCORQUODALE, R, \& FAIRBROTHER, R. 1999. Globalisation and human rights Human Rights Quarterly, 21(3):735-736.

MOOSA, E. 2000. Revival and reform in Islam: a study of Islamic fundamentalism. Oxford. One World. MOOSA, N. 1998. Human rights in Islam. South African Journal on Human Rights, 14:508-524.

NOORANI, AG. 2002. Islam and Jihad: prejudice versus reality. USA. Palgrave.

PRETORIUS. 1998, 20 January. 'n Geloofsaak (A matter of faith). Beeld:8.

RADEMEYER, A. 2006, 7 July. Neusknopie: nog sake oor regte kan kom, sê onderwyskenner. Beeld:5. RONDGANGER, L, \& GOVENDER, P. 2004, 23 January. Wrangler over headscarf at Johannesburg school. Star:3.

SIEGHART, P. 1985. The lawful rights of mankind.

Oxford. Oxford University Press.

SINGH, NK. 1998. Social justice and human rights in Islam. Delhi. Mehra Offset Press.

South African Schools Act, Act 84, RSA.1996.

STRIVING FOR EQUALITY. 1998, 28 May. The Star:20.

TRAER, R. 1991. Faith in human rights - support in religious traditions for a global struggle. Georgetown. Georgetown University Press.

VAN VOLLENHOVEN, WJ. 2005. Learners' Understanding of their Right to Freedom of Expression in South Africa. Unpublished Thesis, University of Pretoria. Pretoria.

VAN VOLLENHOVEN, WJ, \& GLENN, CI. 2004.

Learners' right to freedom of written expression.

South African Journal of Education, 24(2):148-152.

VANDERHAEGHEN, Y. 1998, 25 April. Berks against Burka. The Natal Witness:6.

WIKIPEDIA. 2003. Abu Ghraib torture and prisoner abuse. Available online from http://en.wikipedia.org/ wiki/Abu_Ghraib_prisoner_abuse. Accessed on 7 November 2006.

YILMAZ, I. 2001. Law as chameleon: the question of incorporation of Muslim personal law into the English law. Journal of Muslim Minority Affairs, 21(2):297-308. 